\title{
PERAN SEL NODUS SINOATRIAL SEBAGAI PENGATUR IRAMA JANTUNG
}

\author{
Wahyudi Hardi \\ Sunny Wangko

\begin{abstract}
Bagian Anatomi-Histologi Fakultas Kedokteran Universitas Sam Ratulangi Manado
Email: wahyudi.hardi@ymail.com
\end{abstract}

\begin{abstract}
The heart has a special system that provokes impulses and conducts these in the whole heart, resulting in a contraction. Normally, the sinoatrial node (SA-node) functions as a natural pace maker of the heart which plays a very important role in heart beat regulation. In the SA-node, there are two kinds of cells: $\mathrm{P}$ cell, a specialized nodal cell; and T cell, the transition cell. The P cell, the main SA-nodal cell, is a small cell and contains a small amount of sarcoplasma reticulum, mitochondria, and myofilaments. The $\mathrm{T}$ cell has a larger size, and contains more mitochondria than the $\mathrm{P}$ cell. The action potential in the SA-node begins in the middle of the node (P cells), spreads to the periphery ( $\mathrm{T}$ cells), and then gets into the atrial muscle tissues. $\mathrm{P}$ cells provoke a slower and lower action potential than that of atrial muscles and their surroundings; meanwhile the T cells provoke a faster and larger action potential. In the $\mathrm{P}$ cells, the upstroke action potential occurs slowly since these cells contain a small number of $\mathrm{Na}^{+}$channels, or none. Although $\mathrm{Ca}^{2+} \mathrm{L}$-type channels are responsible for the upstroke action potential in the $\mathrm{P}$ cells, the $\mathrm{Na}^{+}$channels in the $\mathrm{T}$ cells still play some important roles.
\end{abstract}

Keywords: sinoatrial node, $\mathrm{P}$ cell, $\mathrm{T}$ cell, ion channels.

\begin{abstract}
Abstrak: Jantung dilengkapi dengan suatu sistem khusus untuk membangkitkan impulsimpuls dan menghantarkannya dengan cepat ke seluruh jantung sehingga terjadi kontraksi otot jantung. Dalam keadaan normal, nodus sinoatrial (SA) di atrium kanan berperan sebagai pacu alami jantung dan berperan penting dalam mengatur irama jantung. Pada nodus SA terdapat sel P (sel-sel khas nodal) dan sel T (sel transisi). Sel P merupakan sel utama dalam nodus sinoatrial, berukuran kecil, dan hanya mengandung sedikit retikulum sarkoplasma, mitokondria dan miofilamen. Sel T berukuran lebih besar dan mempunyai mitokondria yang lebih banyak dari pada sel P. Potensial aksi pada nodus SA dimulai di daerah tengah nodus SA (sel P), kemudian merambat ke daerah tepi (sel T), lalu masuk ke dalam jaringan otot atrium. Sel P menimbulkan potensial aksi yang lebih lambat dan kecil dibandingkan potensial aksi pada otot atrium dan sekitarnya, sedangkan pada sel T ditemukan potensial aksi yang lebih cepat dan lebih besar. Pada sel P, potensial aksi upstroke (depolarisasi) terjadi lambat karena sel ini hanya mengandung sedikit saluran $\mathrm{Na}^{+}$, bahkan biasanya tidak ada. Meskipun saluran $\mathrm{Ca}^{2+} \mathrm{L}$-type (tipe lambat) yang bertanggung jawab dalam potensial aksi upstroke pada sel $\mathrm{P}$, pada sel T saluran $\mathrm{Na}^{+}$tetap berperan penting. ${ }^{13}$
\end{abstract}

Kata kunci: nodus sinoatrial, sel P, sel T, saluran ion.

Jantung merupakan organ yang terletak di mediastinum bagian tengah, besarnya sekepalan tangan, dan berfungsi untuk memompa darah ke seluruh tubuh pada sirkulasi pulmonal dan sirkulasi sistemik. Jan- tung terdiri dari empat ruangan yaitu: atrium kanan, atrium kiri, ventrikel kanan, dan ventrikel kiri. ${ }^{1}$

Jantung dilengkapi dengan suatu sistem khusus untuk membangkitkan impuls- 
impuls yang berirama sehingga menyebabkan timbulnya kontraksi otot jantung. Selain itu, sistem khusus ini berfungsi untuk mengkonduksikan impuls dengan cepat ke seluruh jantung. Bila sistem konduksi berfungsi normal, atrium akan berkontraksi kira-kira seperenam detik lebih awal dari kontraksi ventrikel sehingga memungkinkan pengisian tambahan pada ventrikel sebelum ventrikel memompa darah ke sirkulasi paru-paru dan sirkulasi sistemik. ${ }^{1,2}$

Sistem perangsangan dan konduksi khusus pada jantung sangat bergantung pada sel-sel pencetus yang mengatur kontraksi jantung yaitu nodus sinoatrial (SA), nodus atrioventrikuler (AV), berkas atrioventrikuler, dan serat Purkinje. Impuls listrik jantung dihasilkan di nodus SA, selanjutnya melalui atrium ke nodus AV mengalami filtrasi dan penundaan, kemudian menuju berkas His dan berakhir pada serat Purkinje. Inisiator peristiwa ini terletak pada aktivitas alat pacu jantung otomatis nodus SA, terjadi depolarisasi spontan diastolik. Potensial aksi dimulai pada kelompok kecil sel di pusat nodus SA, menyebar melalui daerah perifer ke jaringan atrium dan kemudian ke seluruh jantung. ${ }^{1,2}$

Otot jantung mulai berkontraksi beberapa milidetik sesudah potensial aksi mulai dan akan terus berkontraksi selama beberapa detik sesudah potensial aksi berakhir. Seperti halnya otot rangka, otot jantung menggunakan energi kimia untuk menyebabkan kontraksi. Energi ini dihasilkan terutama dari metabolisme oksidatif asam lemak dan sebagian kecil dari bahan makanan lain, khususnya laktat dan glukosa. ${ }^{3}$

Semua sel konduksi pada jantung menghasilkan impuls dan yang digunakan untuk berkontraksi ialah impuls dari nodus SA. Hal ini disebabkan karena nodus SA menghasilkan impuls dengan frekuensi paling besar dan paling cepat. Pada saat semua sel konduksi pada jantung (nodus SA, nodus AV, serat Purkinje) menghasilkan impuls, nodus SA menghasilkan impuls lebih cepat, sehingga dapat membatalkan semua proses pembuatan impuls dari sel-sel konduksi lainnya. Jadi, nodus SA yang mengatur ritme jantung karena kecepatan pelepasan rangsangan tersebut lebih besar daripada sel-sel konduksi lainnya. Oleh karena itu nodus SA merupakan alat pacu yang alami pada jantung. ${ }^{1,2}$

Ritme jantung normal yaitu 60-100x per menit, biasanya disebut irama nodus sinus. Pada keadaan abnormal dan nodus SA tidak mengeluarkan impuls, maka nodus AV dan serat Purkinje dapat mengeluarkan impuls dengan cara sama seperti yang dilakukan oleh nodus SA. Bila nodus AV tidak mendapatkan rangsangan dari sumber luar, maka nodus ini akan mencetuskan rangsangan dengan frekuensi sebesar 40-60x per menit, dan serat Purkinje akan melepaskan rangsangan dengan frekuensi sebesar 15-40x per menit. ${ }^{4}$

Nodus SA sebagai alat pacu alami pada jantung (pacemaker) dan memegang peranan sebagai pengatur ritme jantung. Bila terjadi gangguan pada nodus SA (disfungsi nodus SA), maka akan terjadi irama yang abnormal dari nodus SA sehingga ritme jantung menjadi tidak teratur.

\section{ANATOMI DAN FISIOLOGI JANTUNG}

Jantung merupakan organ berotot yang berkontraksi secara teratur dan memompakan darah melalui sistem sirkulasi. Ukuran jantung kira-kira sebesar kepalan tangan dengan berat sekitar 300 g. Jantung berada dalam rongga toraks antara kedua paruparu di belakang sternum serta menghadap lebih ke arah kiri dari pada ke kanan. Dindingnya terdiri atas tiga lapisan yaitu bagian dalam (endokardium), bagian tengah (miokardium), dan bagian luar (epikardium). ${ }^{5}$

Endokardium merupakan lapisan terdalam dari jaringan yang melapisi ruang jantung. Miokardium merupakan tunika yang paling tebal dari jantung dan terdiri atas sel-sel otot jantung yang tersusun dalam lapisan-lapisan yang mengelilingi atrium dan ventrikel. Bagian luar jantung dilapisi oleh epitel selapis gepeng (mesotel) ditopang oleh selapis tipis jaringan ikat yang membentuk epikardium. Pada lapisan jaringan ikat longgar subepikardium terdapat arteri, vena, saraf, dan ganglia saraf. 5,6 
Sel otot jantung melakukan kontraksi dengan tujuan untuk memompakan darah dan dicetuskan oleh sebuah potensial aksi kemudian menyebar melalui membran sel otot. Kejadian tersebut diakibatkan karena jantung memiliki mekanisme untuk mengalirkan listrik yang ditimbulkannya sendiri untuk melakukan kontraksi atau memompa dan melakukan relaksasi. Mekanisme aliran listrik yang menimbulkan aksi tersebut dipengaruhi oleh beberapa jenis elektrolit seperti $\mathrm{K}^{+}, \mathrm{Na}^{+}$, dan $\mathrm{Ca}^{2+}$, sehingga bila di dalam tubuh terjadi gangguan kadar elektrolit tersebut maka akan menimbulkan gangguan pula pada mekanisme aliran listrik pada jantung. ${ }^{1}$

\section{HISTOLOGI JANTUNG}

Sel-sel otot jantung beranastomosis membentuk tautan yang rumit di antara cabang-cabangnya yang terjulur. Sel-sel di dalam rantai tersebut seringkali bercabang dua, bersambung dengan sel di rantai yang berdekatan, dan terdiri atas berkas-berkas sel yang teranyam erat sedemikian rupa sehingga dapat menimbulkan gelombang kontraksi yang khas pada otot jantung. ${ }^{1}$

Diskus interkalaris merupakan kompleks pertautan yang terdapat pada pertemuan antar sel-sel otot jantung yang bersebelahan, dapat berupa garis lurus atau memperlihatkan pola mirip tangga. Diskus interkalaris mengikat dan secara fungsional menggabungkan semua sel otot jantung sehingga memungkinkan penyebaran cepat dari stimulus untuk kontraksi seluruh muskular jantung. Difusi ion-ion melalui pori taut rekah (gap junction) sel otot jantung memungkinkan penggabungan fungsional dan kordinasi aktivitas di seluruh jantung dan menghasilkan otot jantung yang bekerja sama sebagai satu sinsitium fungsional. $^{1,8}$

\section{Nodus sinoatrial}

\section{Histologi nodus sinoatrial}

Nodus SA tersusun oleh sel-sel otot yang ukurannya lebih kecil dari sel otot atrium, memiliki lebih sedikit myofibril, dan berfungsi sebagai sel konduksi. Sel nodus SA menghasilkan irama yang cepat dalam perangsangan kontraksi jantung dan mengatur kecepatan frekuensi denyut jantung. ${ }^{6}$

Nodus SA terdiri dari matriks jaringan fibrosa dengan sel-sel berdekatan yang berukuran panjang $15 \mathrm{~mm}$, lebar $3 \mathrm{~mm}$, tebal $1 \mathrm{~mm}$ yang sebagian besar divaskularisasi oleh arteri koroner. ${ }^{6,8}$

\section{Nodus sinoatrial sebagai alat pacu jan- tung alami (pacemaker)}

Nodus SA merupakan alat pacu yang alami pada jantung. Pada jantung yang normal, impuls saraf dihasilkan oleh bagian jantung yang disebut pacemaker yang terletak pada nodus sinoatrial. Pacemaker ini bertanggung jawab dalam proses inisiasi potensial aksi secara teratur. ${ }^{10,11}$

Pada nodus SA terdapat sel P (sel-sel khas nodal) dan sel $\mathrm{T}$ (sel transisi). Sel $\mathrm{P}$ merupakan sel utama dalam nodus SA yang ukurannya kecil dan hanya mengandung sedikit retikulum sarkoplasma, mitokondria dan miofilamen. Disamping itu, terdapat juga sel $\mathrm{T}$ yang berukuran lebih besar dan menunjukkan jumlah mitokondria lebih banyak dari pada sel P. Sel T terletak di antara sel P dan sel atrium (Gambar 1). ${ }^{12}$

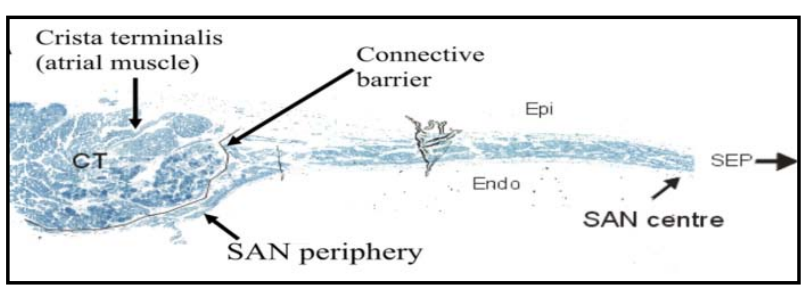

Gambar 1. Sel P (SAN Centre), sel T (SAN periphery) dan otot atrium. Sumber: Boyyet, 2007. ${ }^{12}$

Potensial aksi pada nodus SA dimulai di daerah tengah nodus (sel P), kemudian merambat ke daerah perifer (sel T), dan masuk ke dalam jaringan otot atrium. Sel $\mathrm{P}$ menimbulkan potensial aksi yang lambat dan kecil dibandingkan potensial aksi pada otot atrium dan sekitarnya, sedangkan pada sel $\mathrm{T}$ ditemukan potensial aksi yang lebih 
cepat dan lebih besar. ${ }^{13}$

Pada sel P, potensial aksi upstroke (depolarisasi) lambat karena sel ini hanya mengandung sedikit saluran $\mathrm{Na}^{+}$, bahkan biasanya tidak ada. Meskipun saluran $\mathrm{Ca}^{2+} \mathrm{L}-$ type (tipe lambat) yang bertanggung jawab dalam potensial aksi upstroke pada sel $\mathrm{P}$, pada sel $\mathrm{T}$ saluran $\mathrm{Na}^{+}$tetap berperan penting. ${ }^{13}$

Mekanisme perangsangan nodus SA ke otot atrium melalui interaksi kopling listrik dan diperantarai oleh suatu lapisan jaringan ikat yang bertindak sebagai isolator listrik. Awal dari detak jantung dimulai pada nodus SA di mana terjadi perangsangan saraf vagus yang menyebabkan pelepasan asetilkolin. Pelepasan asetilkolin membuat permeabilitas membran terhadap ion $\mathrm{K}^{+}$meningkat, sehingga saluran $\mathrm{K}^{+}$terbuka. Keluarnya ion $\mathrm{K}^{+}$ke ekstrasel membuat keadaan intrasel menjadi negatif sehingga membuat saluran $\mathrm{Na}^{+}$$\mathrm{Ca}^{2+}$ yang bersifat tegangan (voltage gated) terbuka. Masuknya ion $\mathrm{Na}^{+}$dan $\mathrm{Ca}^{2+} \mathrm{ke}$ dalam intrasel membuat penurunan elektronegatifitas intrasel, yang biasa disebut depolarisasi. Setelah keadaan depolarisasi, saluran $\mathrm{Ca}^{2+}$ dan $\mathrm{Na}^{+}$tetap terbuka tetapi ion $\mathrm{K}^{+}$masuk kembali ke intrasel oleh karena pada akhir potensial aksi membran sel menjadi sangat permeabel terhadap ion $\mathrm{K}^{+}$. Aliran keluar ion $\mathrm{K}^{+}$yang berlangsung secara berlebihan kembali menimbulkan keadaan yang lebih negatif pada intrasel, disebut hiperpolarisasi (Gambar 2). ${ }^{14}$

Hiperpolarisasi secara bertahap akan menghilang, sehingga mempermudah potensial membran meningkat lagi hingga mencapai ambang batas untuk dimulainya lagi perangsangan. Pada saat nodus SA mengalami keadaaan depolarisasi, keadaan di ekstrasel menjadi negatif sehingga membuat saluran $\mathrm{Na}^{+}$sel tetangga (sel otot atrium) menjadi terbuka. Setelah itu. terjadi mekanisme kontraksi otot jantung yaitu bertemunya filamen aktin dan miosin sehingga terjadi kontraksi otot jantung. ${ }^{1}$

\section{Peran saluran ion pada nodus sinoatrial}

Saluran ion dalam nodus SA sangat berperan penting dalam melaksanakan potensial aksi. Berbagai saluran ion sangat menentukan keluarnya impuls dari nodus SA yaitu saluran $\mathrm{K}^{+}\left(\mathrm{I}_{\mathrm{K}}\right)$, saluran $\mathrm{Na}^{+}\left(\mathrm{I}_{\mathrm{Na}}\right)$ dan saluran $\mathrm{Ca}^{2+}\left(\mathrm{I}_{\mathrm{Ca}}\right)($ Gambar 3$) .{ }^{14}$

\section{Saluran $K^{+}\left(I_{K}\right)$}

Mekanisme terbukanya saluran $\mathrm{K}^{+}$pada sel-sel nodus sinoatrial terjadi akibat asetilkolin yang dilepaskan oleh saraf vagus. Hal ini akan menyebabkan peningkatan kenegatifan di dalam sel, keadaan ini disebut hiperpolarisasi. Saluran $\mathrm{K}^{+}$diyakini bertanggung jawab atas bagian awal terjadi potensial aksi pada sel nodus sinoatrial. ${ }^{14}$

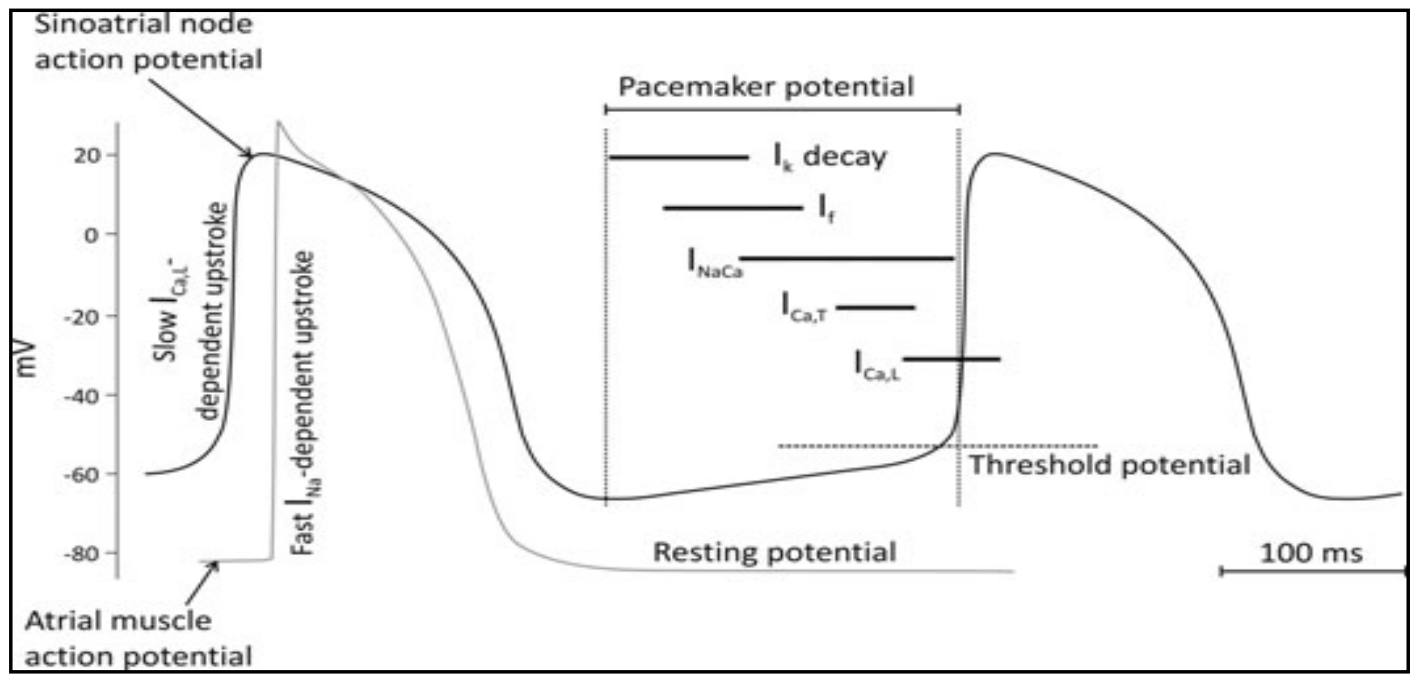

Gambar 2. Potensial aksi pada sel nodus sinoatrial dan otot atrium. Sumber: Boyyet, 2010. ${ }^{14}$ 


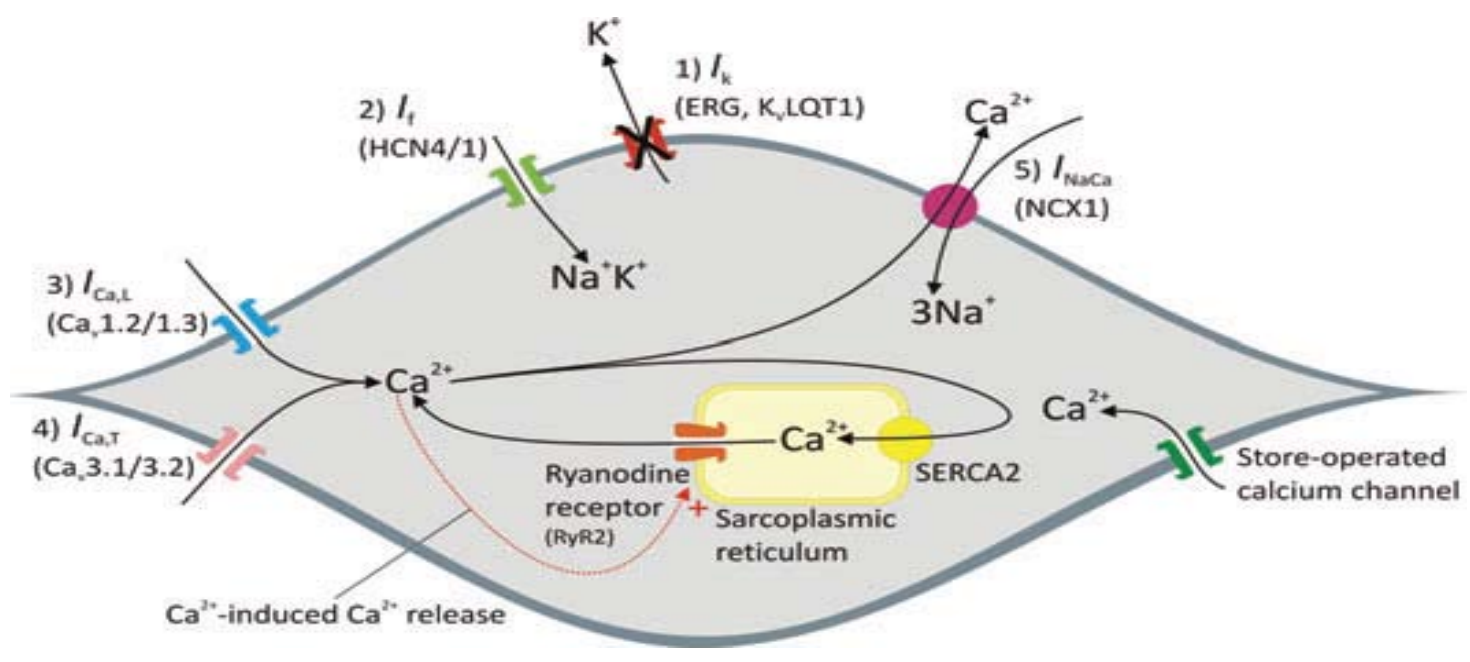

Gambar 3. Gambar nodus sinoatrial beserta lima saluran ion yang terlibat pada aktivitas nodus sinoatrial sebagai pacemaker. Sumber: Boyyet, 2010. ${ }^{14}$

\section{Saluran $\mathrm{Na}^{+}\left(\mathrm{I}_{\mathrm{Na}}\right)$}

Saluran $\mathrm{Na}^{+}$banyak ditemukan pada sel $\mathrm{T}$, tetapi sebaliknya saluran $\mathrm{Na}^{+}$hanya sedikit bahkan tidak ditemukan pada sel P. Pentingnya saluran $\mathrm{Na}^{+}$dalam pacemaker telah diperdebatkan karena pada sel $\mathrm{P}$ jumlahnya sangat sedikit bahkan biasanya tidak ada, namun dengan terdapatnya saluran $\mathrm{Na}^{+}$yang berlimpah pada sel $\mathrm{T}$, maka perannya dalam potensial aksi upstroke menjadi besar. $^{15}$

\section{Saluran $\mathrm{Ca}^{2+}\left(\mathrm{I}_{c a}\right)$}

Saluran $\mathrm{Ca}^{2+}$ sangat penting pada sel nodus SA khususnya pada sel P. Potensial aksi upstroke pada sel $\mathrm{P}$ sangat ber-gantung pada saluran $\mathrm{Ca}^{2+}$ karena sel $\mathrm{P}$ tidak memiliki saluran $\mathrm{Na}^{+}$. Oleh karena itu, ion $\mathrm{Ca}^{2+}$ masuk ke dalam sitoplasma se-hingga terjadi potensial aksi upstroke pada sel $\mathrm{P} .{ }^{14}$

Saluran $\mathrm{Ca}^{2+}$ diaktifkan oleh karena meningkatnya potensial membran pada keadaan yang lebih negatif. Terdapat dua macam saluran $\mathrm{Ca}^{2+}$ pada nodus sinoatrial yaitu saluran $\mathrm{Ca}^{2+} \mathrm{L}$-type dan saluran $\mathrm{Ca}^{2+}$ T-type. Untuk memulai potensial aksi pada sel nodus SA saluran $\mathrm{Ca}^{2+}$ L-type terbuka sehingga keadaan menjadi depolarisasi.

Mekanisme depolarisasi spontan dikaitkan dengan sebuah mekanisme voltage clock. Pengeluaran $\mathrm{Ca}^{2+}$ dari retikulum sarkoplasma sangat berkaitan dengan dimu- lainya irama nodus sinus. Ketika retikulum sarkoplasma penuh, pengeluaran ion $\mathrm{Ca}^{2+}$ spontan meningkat; sebaliknya bila retikulum sarkoplasma kosong kemungkinan untuk pengeluaran ion $\mathrm{Ca}^{2+}$ menurun. ${ }^{14,16}$

\section{Sistem saraf pada nodus sinoatrial}

Nodus SA dipersarafi oleh sistem saraf simpatis dan parasimpatis. Aktivitas sistem saraf parasimpatis pada nodus SA dipersarafi oleh saraf vagus yaitu dilepaskannya hormon asetilkolin pada ujung saraf vagus. Asetilkolin yang dilepaskan pada ujung saraf vagus akan meningkatkan permeabilitas membran terhadap ion $\mathrm{K}^{+}$sehingga akan terjadi terbukanya saluran $\mathrm{K}^{+}$pada sel nodus SA. Hal ini menyebabkan keadaan yang lebih negatif dalam membran sel pada nilai -65 sampai $-75 \mathrm{mV}$ (normalnya -55 sampai -60 mV), yang disebut keadaan hiperpolarisasi.

Awal peningkatan potensial membran nodus SA disebakan oleh masuknya ion $\mathrm{Na}^{+}$dan $\mathrm{Ca}^{2+}$ ke dalam membran sel sehingga terjadi keadaan depolarisasi. ${ }^{1}$

Perangsangan saraf simpatis akan melepaskan hormon norepinefrin pada ujung saraf simpatis. Pelepasan norepinefrin ini akan menyebabkan permeabilitas membran sel terhadap ion $\mathrm{Na}^{+}$dan $\mathrm{Ca}^{2+}$ meningkat. Dalam nodus SA, hal ini akan menyebabkan peningkatan kecepatan fase de- 
polarisasi menuju ke nilai ambang batas potensial membran sehingga terjadi peningkatan frekuensi denyut jantung. ${ }^{1}$

\section{Disfungsi nodus sinus}

Disfungsi nodus sinus pertama kali muncul dalam literatur pada tahun 1968 dengan nama sick sinus syndrome. Disfungsi nodus sinus yaitu keadaan di mana terjadi kelainan pembentukan impuls nodus sinus dan penjalarannya yang sering disertai dengan kelainan serupa di atrium dan sistem konduksi pada jantung.

Pada disfungsi nodus sinus yang ringan, pasien biasanya asimtomatik. Bila keadaan menjadi lebih parah, pasien akan mengalami gejala-gejala seperti kelelahan, pusing, kebingungan, pingsan, dan jantung berdebar-debar yang diakibatkan oleh ketidakteraturan denyut jantung. ${ }^{23}$

Etiologi disfungsi nodus sinus yang tepat biasanya tidak teridentifikasi. Sebagian besar kasus diyakini disebabkan oleh berbagai kombinasi faktor intrinsik dan ekstrinsik. Penyebab intrinsik paling umum yaitu perubahan nodus sinus pada jantung yang terkait dengan penuaan dan penyakit arteri koroner. Penyebab ekstrinsik yang biasa terjadi ialah pengaruh pengobatan yang diberikan kepada pasien, seperti penggunaan obat calcium channel blockers (CCBs). ${ }^{23}$

Pada penuaan, terjadi perubahan struktur sel nodus SA, khususnya saluran ion. Saluran $\mathrm{Na}^{+}$dan $\mathrm{Ca}^{2+}$ berperan penting dalam proses terjadinya potensial aksi upstroke pada sel nodus SA, sehingga berkurangnya saluran $\mathrm{Na}^{+}$dan $\mathrm{Ca}^{2+}$ dapat mengakibatkan gangguan pada irama jantung. ${ }^{24}$

Disfungsi nodus sinus juga diakibatkan oleh faktor ekstrinsik pada sel nodus SA khususnya penggunaan obat CCBs. yang mengakibatkan berkurangnya ion $\mathrm{Ca}^{2+}$ masuk ke dalam intrasel nodus SA. ${ }^{23}$

Seperti yang telah dijelaskan diatas bahwa ion $\mathrm{Ca}^{2+}$ sangat berperan dalam terjadinya potensial aksi upstroke pada sel nodus SA, sehingga pada keadaan dimana terjadi berkurangnya ion $\mathrm{Ca}^{2+}$ masuk ke dalam intrasel, hal ini akan mengakibatkan frekuensi jantung menurun. ${ }^{23,24}$

Inisiasi dan konduksi dari aktivitas alat pacu jantung tidak hanya tergantung pada sifat sel nodus SA, tetapi juga pada struktur anatomi dari sel-sel nodus tersebut. Sel P di bagian tengah yang lebih kecil, memiliki lebih sedikit miofilamen dibandingkan sel $\mathrm{T}$ di bagian perifer nodus SA, sehingga sel $\mathrm{T}$ lebih cepat bereaksi dibandingkan sel $\mathrm{P}$, namun tingkat pacunya ditentukan oleh sel $\mathrm{P}$ karena adanya interaksi listrik antara nodus SA dan atrium. ${ }^{25}$

Nodus SA memiliki kepadatan saluran $\mathrm{Na}^{+}$yang lebih tinggi pada sel $\mathrm{T}$ dibandingkan pada sel P. Zhang et al. ${ }^{25}$ mengukur waktu konduksi nodus SA (SA node atrium conduction time) pada atrium kelinci dan menemukan bahwa banyaknya saluran $\mathrm{Na}^{+}$pada sel $\mathrm{T}$ membantu nodus tersebut untuk menggerakkan atrium. Penghapusan saluran $\mathrm{Na}^{+}$nodus SA dengan pemodelan komputer menyebabkan kecepatan potensial aksi menjadi lambat. Penurunan jumlah sel pada nodus SA juga memiliki efek yang serupa. Bila saluran $\mathrm{Na}^{+}$pada sel $\mathrm{T}$ dan jumlah sel pada nodus SA berkurang, hal ini akan berdampak lebih besar yaitu melemahnya kemampuan nodus SA untuk menggerakkan atrium. ${ }^{25}$

\section{SIMPULAN}

Nodus sinoatrial sebagai alat pacu alami jantung berperan penting dalam mengatur irama jantung. Berbagai keadaan dimana terjadi gangguan sel-sel nodus sinoatrial terutama pada disfungsi nodus sinus khususnya akibat penuaan dapat menyebabkan gangguan irama jantung.

Pada disfungsi nodus sinus akibat penuaan, terjadi penurunan jumlah saluran $\mathrm{Na}^{+}$pada sel nodus SA. Keadaan ini meyebabkan gangguan konduksi impuls pada sel-sel nodus tersebut, yang dapat menyebabkan irama jantung melambat.

\section{DAFTAR PUSTAKA}

1. Guyton \& Hall. Buku Ajar Fisiologi 
Kedokteran (Edisi Kesebelas). Alih Bahasa: Irawati. Jakarta: EGC, 2007; hal.103,104,116,121,147.

2. Opie LH. Heart Physiology. From cell to circulation (Fourth Edition). Philadelphia: Lippincott Williams \& Wilkins, 2006; p.119.

3. Katz AM. Physiology of Heart (Fifth Edition). Philadelphia: Lippincott Williams \& Wilkins, 2011; p.431.

4. Cohen TJ. A Patient's Guide to Heart Rhythm Problems. Maryland: The John Hopkins University Press, 2010; p.13.

5. Pearce EC. Anatomi dan Fisiologi untuk Paramedis. Alih Bahasa: Handoyo SY. Jakarta: Gramedia Pustaka Utama, 2008; hal.143-4.

6. Junqueira LC, Carneiro J. Histologi Dasar (Edisi Kesepuluh). Alih Bahasa: Tambayong J. Jakarta: EGC, 2007; hal. 213-4.

7. Grant AO, Durrani S. Textbook of Cardiovascular Medicine (Third Edition). Philadelphia: Lippincott Williams \& Wilkins, 2007; p.E57-3.

8. Eroschenko VP. Atlas Histologi di Fiore dengan Kolerasi Fungsional. Alih Bahasa: Tambayong J. Jakarta: EGC, 2003; hal. 80,82.

9. Boyett MR, Dobrzynski H. The sinoatrial node is still setting the pace 100 years after its discovery. Circ Res. 2007;100: 1543-45.

10. Bucchi A, Plotnikov AN, Shlapakova I, Danilo P Jr, Kryukova Y, Qu J. Wild-type and mutant HCN channels in a tandem biological-electronic cardiac pacemaker. Circ Res. 2006;114: 992-999.

11. Vinogradova TM. Sinoatrial node pacemaker activity requires $\mathrm{Ca}^{2+} / \mathrm{cal}-$ modulin-dependent protein kinase II activation. AHA. 2000;87:760-767.

12. Boyyet MR, Honjo H, Kodama I. The sinoatrial node a heterogeneous pacemaker structure. Cardiovasc Res. 2000;47(4).658-687.

13. Dobrzynski H, Boyyet MR. New insight into pacemaker activity : Promoting understanding of sick sinus syndrome. Circ Res. 2007;115:1921-1932.

14. Boyyet MR, Monfredi O, Mondal T. The anatomy and physiology of the sinoatrial node-A comtemporary review. Cardiovasc Med. 2010;33: 1392-1406.

15. Verkerk AO, Wilders R, Tan HL. Is the sodium current present in the human sinoatrial node? I nt J Biol Sci. 2009;5:201-204.

16. Joung B, Ogawa $M$. The calcium and voltage clocks in sinoatrial node automaticity. Korea Circ Journal. 2009. Doi : 10.4070/kcj. 2009;39.6.217.

17. Fozzard HA. Ion channels and cardiac function. In: Harber EH ed. Scientific American Molecular Cardiovascular Medicine. New York: Scientific American INC, 2001;211-24.

18. Waldo AL, Wit AL. Mechanism of Cardiac Arrhytmias and Conduction Disturbances. In: Alexander R.W, Schlant R.C, Fuster V. eds. The Heart Arteries and Veins. $9^{\text {th }}$ ed. New York: Mc Graw Hill, 2000;81-115.

19. Bryg RJ. Potassium and your heart. WebMD medical reference [homepage on the Internet]. Nodate [cited 2011 Aug 20]. Available from URL: http://www.webmd.com/heart-disease/ potassium-and-your-heart

20. Blatter LA, Kockskamper J, Sheehan KA. Local calcium gradients during excitation-contraction coupling and alternans in atrial myocytes. J Physiol. 2003;546:19.

21. Ferrier GR, Howlett SE. Cardiac excitation-contraction coupling: Role of membrane potential in regulation of contraction. Am J Physiol Heart Circ Physiol. 2002;280:H1928.

22. Arsenian MA. Magnesium and Cardiovascular Disease. Progress in Cardiovascular Disease. 2000;35:271-310.

23. Yang Yingbo. Sinus node dysfunction [homepage on the Internet]. 2011 [cited 2011 Aug 25]. Avalaible from URL : http://emedicine.medscape.com/ article/158064-overview\#showall

24. Baruscotti M, Robinson RB. Electrophysiology and pacemaker function of the developing sinoatrial node. Am J Physiol Heart Circ Physiol. 2007 Nov;293(5):H2613-23.

25. Zhang $H$, Zhao $Y$, Dobrzynski $H$. Computational evaluation of the roles of $\mathrm{Na}+$ current, iNa, and cell death in cardiac pacemaking and driving. Am J Physiol Heart Circ Physiol. 2007 Jan;292(1):H165-74. 